\title{
Feeding frequency for lactating cows: effects on rumen fermentation and blood metabolites and hormones
}

\author{
BY J. D. SUTTON*, I. C. HART†, W. H. BROSTER \\ ROSEMARY J. ELLIOTT* AND E. SCHULLER* \\ National Institute for Research in Dairying§, Shinfield, Reading RG2 $9 A T$
}

(Received 12 February 1985 - Accepted 23 January 1986)

\begin{abstract}
1. The present paper reports the effects on rumen fermentation and plasma metabolites and hormones of giving fixed rations of hay and high-cereal concentrates at different meal frequencies to lactating cows. In Expt 1 the total ration was given in two and twenty-four meals daily and in Expts 2-4 the concentrates were given in two and five or six meals and the hay in two meals daily. The diets contained $600-920 \mathrm{~g}$ concentrates $/ \mathrm{kg}$.

2. In Expt 1, minimum rumen $\mathrm{pH}$ was higher but mean $\mathrm{pH}$ was lower when cows were given their ration in twenty-four meals/d rather than two meals/d.

3. In all the experiments, the effects of increased meal frequency on the molar proportions of rumen volatile fatty acids (VFA) were small and not significant, although there was a general tendency for the proportion of acetic acid to increase and that of propionic acid to fall. Increasing the proportion of concentrates in the diet reduced the proportion of acetic acid and increased the proportions of propionic and $n$-valeric acids.

4. In Expt 3, more frequent feeding was found to reduce the concentration of non-esterified fatty acids in the blood, but changes in other metabolites were small and not significant. Increasing the proportion of concentrates in the diet reduced the concentrations of acetic acid and 3-hydroxybutyric acid and increased the concentrations of propionic acid and glucose.

5. The mean daily concentration of insulin in the blood was reduced by more frequent feeding of the higher-concentrate diet but not of the lower-concentrate diet. The concentration of glucagon also tended to fall with more frequent feeding. Increasing the proportion of concentrates in the diet increased the concentration of insulin.

6. More frequent feeding reduced the depression in milk-fat concentration caused by feeding the low-roughage diets. About three-quarters of the variation in milk-fat concentration could be related to changes in rumen VFA proportions, but the relations for the two meal frequencies had different intercepts although similar curves. The results suggest that milk-fat depression on low-roughage diets with twice-daily feeding was due to a change in rumen VFA proportions accompanied by elevated plasma insulin concentrations. The improvement in milk-fat concentration due to more frequent feeding could be explained partly by the small change in rumen VFA proportions and partly by a reduction in mean plasma insulin concentrations, but these mechanisms did not fully account for the milk-fat responses observed.
\end{abstract}

In a previous paper it was clearly demonstrated that when the concentrates in a low-roughage diet were given in several meals daily rather than in two meals at milking time, the milk-fat depression caused by the diets was reduced (Sutton et al. 1985). Similar results were obtained by Kaufmann et al. (1975), who suggested that the response could be ascribed to an increase in the ratio of the molar proportions of acetate:propionate in the rumen volatile fatty acids (VFA). Milk-fat depression induced by low-roughage diets is certainly closely related to the type of fermentation in the rumen, but various theories have been advanced to explain the association. None has gained universal acceptance, but the suggestion that insulin is closely involved (McClymont \& Vallance, 1962) has received considerable experimental support.

Present addresses: * Animal and Grassland Research Institute, Hurley, Maidenhead, Berks SL6 5LR. † Coopers Animal Health Ltd, Berkhamsted Hill, Berkhamsted, Herts. $\ddagger$ Department of Agriculture and Horticulture, University of Reading, Earley Gate, Reading.

$\S$ Now the Animal and Grassland Research Institute, Shinfield, Reading RG2 9AQ. 
In the present paper the effects of altered meal frequency on rumen fermentation, and blood metabolites and hormones in lactating cows are reported, and the results are discussed in relation to the production responses reported previously (Sutton et al. 1985).

\section{EXPERIMENTAL}

Results of four experiments are reported. The main experimental details were described in a previous paper (Sutton et al. 1985) and they will only be summarized here. In each experiment two diets, differing in their hay:concentrates value, were given at two frequencies to lactating Friesian cows. The diets consisted of long hay and pelleted concentrates; in Expt 1 only, coarsely chopped hay and flaked maize were also given.

Expt 1. Three rumen-fistulated cows were used. They were given daily $5.5 \mathrm{~kg}$ hay plus $10 \cdot 8 \mathrm{~kg}$ concentrates $(660 \mathrm{~g}$ concentrates $/ \mathrm{kg}$ ) and either (cows A and B) $1.0 \mathrm{~kg}$ hay, $5.5 \mathrm{~kg}$ concentrate and $5.5 \mathrm{~kg}$ flaked maize (diet LR1; $920 \mathrm{~g}$ concentrates $/ \mathrm{kg}$ ) or (cow C) $1.6 \mathrm{~kg}$ hay plus $13.9 \mathrm{~kg}$ concentrates (diet LR2; $900 \mathrm{~g}$ concentrates $/ \mathrm{kg}$ ). Each diet was given in two or twenty-four meals daily at equal intervals over the $24 \mathrm{~h}$. At least 3 weeks were allowed for change-over and adaptation to each change of diet and at least 2 weeks for adaptation to a change of frequency. During a 2-week period, samples of rumen fluid were taken through the fistula on four well-separated days 3 and $8 \mathrm{~h}$ after the morning feed on twice-daily feeding and once during the day on hourly feeding. On $2 \mathrm{~d}$, at least 1 week apart, samples of rumen fluid were taken as follows: on twice-daily feeding, before (0) and $0.5,1,2,3$, $4,5,6,8,10$ and $12 \mathrm{~h}$ after the morning feed; on hourly feeding, nine samples at 90 -min intervals during the day, alternately $15 \mathrm{~min}$ after or $15 \mathrm{~min}$ before an hourly feed. On each occasion samples were taken from the ventral sac, the posterior ventral sac, the reticulum and the centre of the rumen by means of a frame kept in the rumen throughout the sampling period, and were mixed before the $\mathrm{pH}$ was measured. With hourly feeding, the $\mathrm{pH}$ was measured in only three samples at six-hourly intervals.

Expt 2. Sixteen first-calf Friesian cows were given either $6.0 \mathrm{~kg}$ hay and $9.0 \mathrm{~kg}$ concentrates $(600 \mathrm{~g}$ concentrates $/ \mathrm{kg})$ or $1.4 \mathrm{~kg}$ hay and $12.6 \mathrm{~kg}$ concentrates $(900 \mathrm{~g}$ concentrates $/ \mathrm{kg})$ daily. Half the cows were given their hay and concentrates in two meals at 06.00 and 14.30 hours and the other half were given their hay in three meals and their concentrates in five meals at $06.00,10.30,14.30,17.00$ and 21.30 hours. Rumen samples were taken by stomach tube 6 and 10 weeks after introduction of the diets. With twice-daily feeding, samples were taken at 09.00 and 14.00 hours, and with five times daily feeding they were taken at 09.00 , 12.00 and 16.00 hours. Previous experience with experiments of this type and the precautions taken ensured that carry-over effects from the previous experiment (a comparison of high- and low-protein diets) would not be a problem.

Expt 3. Sixteen Friesian cows were given either $5.0 \mathrm{~kg}$ hay and $11.5 \mathrm{~kg}$ concentrates daily $(700 \mathrm{~g}$ concentrates $/ \mathrm{kg}$ ) or $1.6 \mathrm{~kg}$ hay and $14.0 \mathrm{~kg}$ concentrates $(900 \mathrm{~g}$ concentrates $/ \mathrm{kg})$ daily. Half the cows were given their feed twice daily and the feeding and rumen sampling routines were as in Expt 2. For frequent feeding, the other half were given their concentrates every $4 \mathrm{~h}$ from 06.30 hours and their hay at 06.00 and 16.45 hours and rumen samples were taken at 14.00 hours. Rumen samples were taken by stomach tube on weeks $9,15,21$ and 27 of lactation. In addition, blood samples were taken every hour for $24 \mathrm{~h}$ by means of an indwelling jugular catheter at approximately 6 (early lactation) and 22 (mid-lactation) weeks of lactation.

Expt 4. Sixteen Friesian cows were given either $6.7 \mathrm{~kg}$ hay and $10.0 \mathrm{~kg}$ concentrates $(600 \mathrm{~g}$ concentrates $/ \mathrm{kg})$ or $3.2 \mathrm{~kg}$ hay and $12.8 \mathrm{~kg}$ concentrates $(800 \mathrm{~g}$ concentrates $/ \mathrm{kg})$ daily. Feeding and rumen sampling routines were as in Expt 3, but no blood sample was taken. 
Sample processing and analysis. Rumen samples were stored at $-20^{\circ}$ and were subsequently analysed for concentrations of volatile fatty acids (VFA) by gas-liquid chromatography (Sutton \& Johnson, 1969) using a Pye 104 gas chromatograph.

Blood samples were taken into heparinized centrifuge tubes, chilled in ice and centrifuged. The plasma was stored at $-20^{\circ}$. The samples were subsequently analysed for concentrations of VFA, glucose, non-esterified fatty acids (NEFA), 3-hydroxybutyric acid (3HBA), growth hormone $(\mathrm{GH})$, prolactin, insulin and thyroxine as described by Hart et al. (1978). Glucagon was determined by the radioimmunoassay technique of Alford et al. (1977).

\section{RESULTS}

\section{Rumen $p H$ and VFA concentration}

With twice-daily feeding the range in rumen $\mathrm{pH}$ following feeding was between 1.3 and 1.9 units, with no clear difference due to diet type (Table 1). With hourly feeding the range in $\mathrm{pH}$ during the day was very small and mean $\mathrm{pH}$ was lower on the low-roughage diets than on the normal diets. The mean $\mathrm{pH}$ with frequent feeding was $0.3-0.9$ unit lower than the mean with twice-daily feeding and on only one occasion, cow A on the normal diet, was the mean above $6 \cdot 0$. In consequence, $\mathrm{pH}$ in the rumen fluid of the cows when they were fed twice daily was lower than that when they were fed hourly for only $2 \cdot 5-5 \mathrm{~h}$ in each feeding cycle. This is illustrated for cow $\mathrm{C}$ in Fig. 1.

The VFA concentrations tended to mirror $\mathrm{pH}$ values (Table 1). Mean concentrations were considerably higher with frequent feeding and the diurnal range in concentration was greatly reduced. There was little difference in either the mean value or the diurnal range due to type of diet.

When rumen samples were taken less frequently during the day in Expt 1 (Table 2), the measured increase in total VFA concentration due to more frequent feeding was much lower. This was largely because, with twice daily feeding, the calculated daily mean concentration was higher when based on samples taken 3 and $8 \mathrm{~h}$ after feeding than when based on samples taken hourly, implying that this restricted sampling routine tended to result in an overestimate of the true mean concentration with infrequent feeding. With the restricted sampling routine based on a stomach tube used in Expts 2-4, no consistent effect of feeding frequency on the concentration of total VFA was apparent (Tables 3-5).

\section{Rumen VFA proportions}

Expt 1. With all the cows when given the normal diet, more frequent feeding increased the molar proportions of acetic and $n$-butyric acids and reduced those of propionic and $n$-valeric acids, thereby increasing the ratio, (acetic $+n$-butyric):propionic $((\mathrm{A}+\mathrm{B}) / \mathrm{P})$ (Table 2$)$. With the low-roughage diets given twice daily, $(\mathrm{A}+\mathrm{B}) / \mathrm{P}$ was much lower than with the normal diet fed twice daily. When the same low-roughage diets were given more frequently, responses were very variable with the result that $(A+B) / P$ increased in cow $A$, fell in cow $\mathrm{B}$ and hardly changed in cow $\mathrm{C}$. In all three cows the proportion of $n$-valeric acid fell sharply with more frequent feeding of both diet types.

Expts 2-4. The effects of concentrate: hay and meal frequency on rumen VFA were similar in all three experiments (Tables 3-5). In each of the experiments more frequent feeding increased the proportion of acetic acid and $(A+B) / P$ and decreased the proportion of propionic acid with each diet, but in no case was the response significant. There were the expected large effects of reducing the proportion of hay on VFA proportions, namely decreases in the proportion of acetic acid and $(\mathrm{A}+\mathrm{B}) / \mathrm{P}$ and increases in the proportions of propionic and $n$-valeric acids. The effects of both concentrate:hay value and meal frequency on the proportion of $n$-butyric acid were generally small and inconsistent. 
Table 1. Expt 1. Daily $\mathrm{pH}$ and concentration of total volatile fatty acids $(\mathrm{mmol} / \mathrm{l})$ in the rumen fluid of three cows given a normal diet or one of two low-roughage diets in two or twenty-four meals daily

(Values for each cow are the means of samples taken at frequent intervals for $12 \mathrm{~h}$ periods on each of $2 \mathrm{~d}$ )

\begin{tabular}{|c|c|c|c|c|c|c|}
\hline \multicolumn{2}{|c|}{ No. of meals/d... } & \multicolumn{3}{|c|}{2} & \multicolumn{2}{|c|}{24} \\
\hline Diet & Cow & Mean & Maximum & Minimum & Mean & Range \\
\hline \multicolumn{7}{|c|}{ Rumen pH } \\
\hline Normal & $\begin{array}{l}\text { A } \\
\text { B } \\
\text { C }\end{array}$ & $\begin{array}{l}6 \cdot 7 \\
6 \cdot 2 \\
6 \cdot 2\end{array}$ & $\begin{array}{l}7.2 \\
6.9 \\
6.7\end{array}$ & $\begin{array}{l}5 \cdot 7 \\
5 \cdot 3 \\
5 \cdot 3\end{array}$ & $\begin{array}{l}6 \cdot 3 \\
5 \cdot 9 \\
5 \cdot 9\end{array}$ & $\begin{array}{l}0 \cdot 1 \\
0 \cdot 2 \\
0 \cdot 1\end{array}$ \\
\hline Low-roughage & $\begin{array}{l}\text { A (LR } 1) \\
\text { B (LR1) } \\
\text { C (LR2) }\end{array}$ & $\begin{array}{l}6 \cdot 4 \\
6 \cdot 3 \\
5 \cdot 8\end{array}$ & $\begin{array}{l}7 \cdot 1 \\
6 \cdot 9 \\
6 \cdot 5\end{array}$ & $\begin{array}{l}5 \cdot 2 \\
5 \cdot 6 \\
5 \cdot 1\end{array}$ & $\begin{array}{l}5 \cdot 5 \\
5 \cdot 8 \\
5 \cdot 5\end{array}$ & $\begin{array}{l}0 \cdot 3 \\
0 \cdot 1 \\
0 \cdot 2\end{array}$ \\
\hline \multicolumn{7}{|c|}{ Rumen total $V F A$} \\
\hline Normal & $\begin{array}{l}\text { A } \\
\text { B } \\
\text { C }\end{array}$ & $\begin{array}{l}75 \\
87 \\
96\end{array}$ & $\begin{array}{l}120 \\
138 \\
141\end{array}$ & $\begin{array}{l}43 \\
57 \\
59\end{array}$ & $\begin{array}{l}103 \\
115 \\
113\end{array}$ & $\begin{array}{r}20 \\
8 \\
13\end{array}$ \\
\hline Low-roughage & $\begin{array}{l}\text { A } \\
\text { B } \\
\text { C }\end{array}$ & $\begin{array}{r}68 \\
79 \\
100\end{array}$ & $\begin{array}{l}115 \\
113 \\
144\end{array}$ & $\begin{array}{l}27 \\
48 \\
69\end{array}$ & $\begin{array}{l}131 \\
111 \\
125\end{array}$ & $\begin{array}{r}13 \\
7 \\
8\end{array}$ \\
\hline
\end{tabular}

LR 1, $920 \mathrm{~g}$ concentrates $/ \mathrm{kg}$ diet; LR2, $900 \mathrm{~g}$ concentrates $/ \mathrm{kg}$ diet.
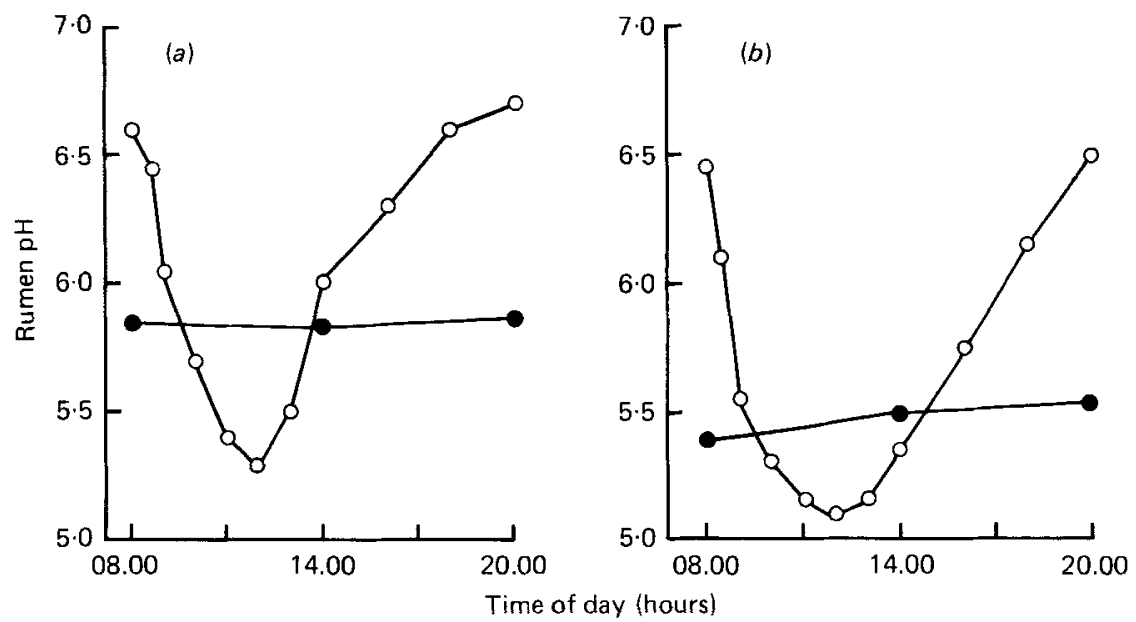

Fig. 1. Expt 1. Rumen pH in cow $\mathrm{C}$ when given $(a)$ the normal diet or (b) the low-roughage diet (LR2) in either two $(O)$ or twenty-four $(O)$ meals daily. 
Feeding frequency and metabolism in cows

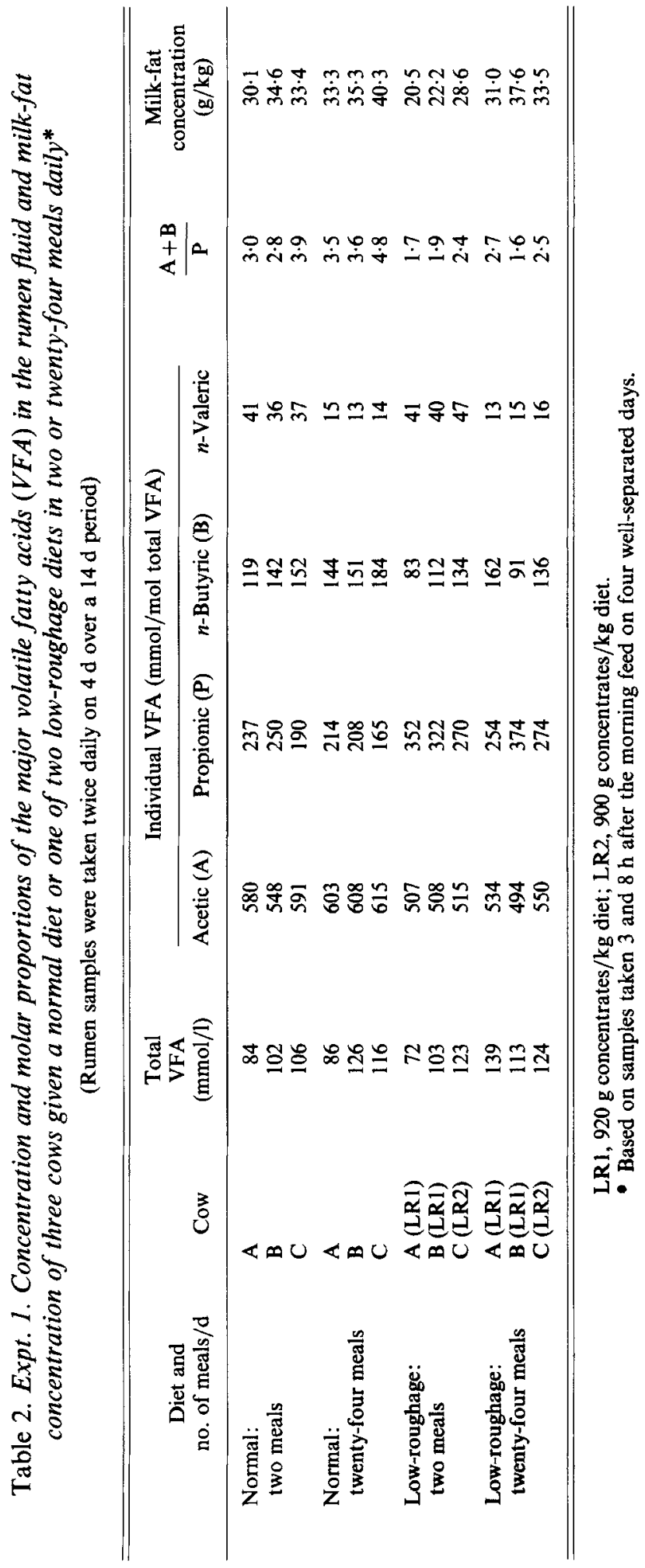


Table 3. Expt 2. The concentration and molar proportions of volatile fatty acids $(V F A)$ and (acetic plus $\mathrm{n}$-butyric):propionic $((A+B) / P)$ in the rumen and milk-fat concentration of cows given two diets each at two meal frequencies

\begin{tabular}{|c|c|c|c|c|c|c|c|c|}
\hline \multirow{2}{*}{$\begin{array}{l}\text { Concentrates: hay... } \\
\text { No. of meals/d... }\end{array}$} & \multicolumn{2}{|c|}{$60: 40$} & \multicolumn{2}{|c|}{$90: 10$} & \multirow{2}{*}{$\begin{array}{l}\text { SEM } \\
(12 \mathrm{df})\end{array}$} & \multicolumn{2}{|c|}{ Main effect } & \multirow[b]{2}{*}{ Interaction } \\
\hline & 2 & 5 & 2 & 5 & & Diet & Frequency & \\
\hline Total VFA (mmol/l) & 50 & 65 & 60 & 66 & $11 \cdot 2$ & NS & NS & NS \\
\hline \multicolumn{9}{|l|}{$\begin{array}{l}\text { Individual VFA } \\
\text { (mmol/mol total VFA) }\end{array}$} \\
\hline Acetic (A) & 656 & 667 & 555 & 564 & $14 \cdot 3$ & $* * *$ & NS & NS \\
\hline Propionic (P) & 157 & 147 & 285 & 259 & $22 \cdot 6$ & $* * *$ & NS & NS \\
\hline Isobutyric & 7 & 10 & 5 & 9 & 0.9 & NS & $* *$ & NS \\
\hline$n$-Butyric (B) & 146 & 141 & 96 & 127 & 10.7 & $*$ & NS & NS \\
\hline Isovaleric & 16 & 16 & 8 & 16 & $1 \cdot 5$ & $*$ & $*$ & $*$ \\
\hline$n$-Valeric & 17 & 16 & 36 & 23 & 3.7 & $* *$ & NS & NS \\
\hline n-Caproic & 3 & 4 & 12 & 3 & $1 \cdot 5$ & $*$ & $*$ & $* *$ \\
\hline$(\mathrm{A}+\mathrm{B}) / \mathrm{P}$ & $5 \cdot 2$ & 5.5 & $2 \cdot 4$ & 2.9 & 0.35 & $* * *$ & NS & NS \\
\hline $\begin{array}{l}\text { Milk-fat } \\
\text { concentration }(\mathrm{g} / \mathrm{kg})\end{array}$ & 39.9 & $36 \cdot 3$ & $18 \cdot 6$ & $28 \cdot 7$ & $1.73+$ & $* * *$ & NS & $* *$ \\
\hline
\end{tabular}

NS, not significant.

$* P<0.05, * * P<0.01, * * * P<0.001$.

$\dagger 11 \mathrm{df}$, since values adjusted by covariance on weeks $11-13$ of lactation.

Table 4. Expt 3. The concentration and molar proportions of volatile fatty acids $(V F A)$ and (acetic plus $\mathrm{n}$-butyric): propionic $((A+B) / P$ ) in the rumen and milk-fat concentration of cows given two diets each at two meal frequencies

\begin{tabular}{|c|c|c|c|c|c|c|c|c|}
\hline \multirow{2}{*}{$\begin{array}{l}\text { Concentrates: hay... } \\
\text { No. of meals/d... }\end{array}$} & \multicolumn{2}{|c|}{$70: 30$} & \multicolumn{2}{|c|}{$90: 10$} & \multirow{2}{*}{$\begin{array}{c}\text { SEM } \\
(12 \mathrm{df})\end{array}$} & \multicolumn{2}{|c|}{ Main effect } & \multirow[b]{2}{*}{ Interaction } \\
\hline & 2 & 6 & 2 & 6 & & Diet & Frequency & \\
\hline $\begin{array}{l}\text { Total VFA (mmol/l) } \\
\text { Individual VFA } \\
\text { (mmol/mol total VFA) }\end{array}$ & 83 & 68 & 83 & 68 & $6 \cdot 7$ & NS & $*$ & NS \\
\hline Acetic (A) & 646 & 654 & 521 & 561 & $17 \cdot 5$ & $* * *$ & NS & NS \\
\hline Propionic (P) & 172 & 163 & 289 & 275 & $20 \cdot 7$ & $* * *$ & NS & NS \\
\hline Isobutyric & 8 & 9 & 6 & 12 & $1 \cdot 3$ & NS & $*$ & NS \\
\hline$n$-Butyric (B) & 128 & 138 & 114 & 107 & $10 \cdot 4$ & NS & NS & NS \\
\hline Isovaleric & 23 & 16 & 8 & 22 & $2 \cdot 8$ & NS & NS & $* *$ \\
\hline$n$-Valeric & 18 & 15 & 42 & 22 & $2 \cdot 7$ & $* * *$ & $* * *$ & $* *$ \\
\hline n-Caproic & 5 & 5 & 20 & 4 & $1 \cdot 2$ & $* * *$ & $* * *$ & *** \\
\hline$(\mathrm{A}+\mathrm{B}) / \mathrm{P}$ & $4 \cdot 5$ & $4 \cdot 9$ & $2 \cdot 2$ & $2 \cdot 6$ & 0.29 & $* * *$ & NS & NS \\
\hline $\begin{array}{l}\text { Milk-fat } \\
\text { concentration }(\mathrm{g} / \mathrm{kg})\end{array}$ & $32 \cdot 6$ & $39 \cdot 2$ & 17.9 & $29 \cdot 7$ & $2 \cdot 01$ & $* * *$ & $* * *$ & NS \\
\hline
\end{tabular}

NS, not significant.

* $P<0.05,{ }^{* *} P<0.01,{ }^{* * *} P<0.001$. 
Table 5. Expt 4. The concentration and molar proportions of volatile fatty acids $(V F A)$ and (acetic plus $\mathrm{n}$-butyric) : propionic $((A+B) / P)$ in the rumen and milk-fat concentration of cows given two diets each at two meal frequencies

\begin{tabular}{|c|c|c|c|c|c|c|}
\hline \multirow{2}{*}{$\begin{array}{l}\text { Concentrates: hay... } \\
\text { No. of meals } / \mathrm{d} \ldots\end{array}$} & \multicolumn{2}{|c|}{$60: 40$} & \multicolumn{2}{|c|}{$80: 20$} & \multirow{2}{*}{$\begin{array}{l}\text { SEM } \\
(12 \mathrm{df})\end{array}$} & \multirow{2}{*}{$\frac{\text { Main effect } t}{\text { Diet }}$} \\
\hline & 2 & 6 & 2 & 6 & & \\
\hline $\begin{array}{l}\text { Total VFA }(\mathrm{mmol} / \mathrm{l}) \\
\text { Individual VFA } \\
\text { (mmol/mol total VFA) }\end{array}$ & 73 & 65 & 77 & 80 & $7 \cdot 2$ & NS \\
\hline Acetic $(A)$ & 679 & 702 & 598 & 616 & $15 \cdot 0$ & *** \\
\hline Propionic (P) & 163 & 148 & 220 & 198 & 14.3 & $* *$ \\
\hline Isobutyric & 9 & 10 & 9 & 11 & 1.0 & NS \\
\hline$n$-Butyric & 116 & 108 & 117 & 133 & $5 \cdot 0$ & $*$ \\
\hline Isovaleric & 17 & 16 & 24 & 23 & 0.9 & $* * *$ \\
\hline$n$-Valeric & 13 & 12 & 24 & 17 & $2 \cdot 4$ & ** \\
\hline$n$-Caproic & 3 & 4 & 8 & 2 & 1.9 & NS \\
\hline$(\mathrm{A}+\mathrm{B}) / \mathrm{P}$ & 4.9 & $5 \cdot 5$ & $3 \cdot 4$ & $3 \cdot 9$ & 0.34 & $* * *$ \\
\hline $\begin{array}{l}\text { Milk-fat } \\
\text { concentration }(\mathrm{g} / \mathrm{kg})\end{array}$ & $34 \cdot 3$ & $36 \cdot 2$ & 31.6 & $35 \cdot 3$ & $0.87 \ddagger$ & NS \\
\hline
\end{tabular}

NS, not significant.

${ }^{*} P<0.05,{ }^{* *} P<0.01,{ }^{* * *} P<0.001$.

$\uparrow$ The only significant effect of frequency was for milk-fat concentration $(P<0.01)$. The only significant interaction $(P<0.05)$ was for $n$-butyric acid.

$\ddagger 11 \mathrm{df}$, since values adjusted by covariance on week 3 of lactation.

In each of these experiments the proportion of $n$-caproic acid was greatly reduced by more frequent feeding of the low-roughage diets but was unaffected with the higher-roughage diets. There was a similar though smaller trend with $n$-valeric acid.

\section{Blood metabolites}

There was no consistent effect of meal frequency on the concentration of any of the VFA at any single stage of lactation, although for both stages combined more frequent feeding decreased the concentration of total VFA and acetic acid $(P<0.05)$ (Table 6). Reducing the proportion of hay increased the concentration of propionic acid and reduced the concentrations of acetic acid, $n$-valeric acid and total VFA.

More frequent feeding reduced the concentration of NEFA at both stages of lactation but had inconsistent effects on the concentrations of glucose and 3HBA. Reducing the proportion of hay increased the concentration of glucose and reduced the concentration of $3 \mathrm{HBA}$ at both stages.

\section{Plasma hormones}

More frequent feeding reduced the concentration of insulin with the higher-concentrate diet but not with the lower-concentrate diet (Table 7). The concentration of glucagon was lower with more frequent feeding in all comparisons, the effect being significant in mid-lactation $(P<0.01)$.

The concentration of insulin was increased by reducing the roughage content of the diet, the effect being greater in mid-lactation than in early lactation. The only other significant effect of diet type on hormones was a higher concentration of prolactin with the lowerroughage diet in mid-lactation only.

The concentration of all the hormones was affected by stage of lactation, the concentrations of prolactin $(P<0.001)$, insulin $(P<0.01)$ and glucagon $(P<0.01)$ being greater, and those of growth hormone $(P<0.001)$ and thyroxine $(P<0 \cdot 10)$ being lower in mid-lactation. 
Table 6. Expt 3. The mean daily concentration ( $m$ mol/l) of various metabolites in the blood of cows at two stages of lactation (about 6 and 22 weeks of lactation) when they were given two diets each at two meal frequencies

\begin{tabular}{|c|c|c|c|c|c|c|c|c|}
\hline \multirow{3}{*}{$\begin{array}{l}\text { Concentrates: hay... } \\
\text { No. of meals } / \mathrm{d} . .\end{array}$} & \multirow{3}{*}{$\begin{array}{c}\text { Stage } \\
\text { (weeks) }\end{array}$} & \multicolumn{2}{|c|}{$70: 30$} & \multicolumn{2}{|c|}{$90: 10$} & \multirow[b]{3}{*}{ SEM $\dagger$} & \multirow{2}{*}{\multicolumn{2}{|c|}{ Main effect $\ddagger$}} \\
\hline & & \multirow[t]{2}{*}{2} & \multirow[t]{2}{*}{6} & \multirow[t]{2}{*}{2} & \multirow[t]{2}{*}{6} & & & \\
\hline & & & & & & & Diet & Frequency \\
\hline \multirow{2}{*}{$\begin{array}{l}\text { Total volatile } \\
\text { fatty acids }\end{array}$} & 6 & $1 \cdot 28$ & $1 \cdot 13$ & 0.96 & 0.881 & \multirow{2}{*}{0.077} & $\{* *$ & NS \\
\hline & 22 & $1 \cdot 20$ & 1.07 & 0.86 & 0.84 & & ** & NS \\
\hline \multirow[t]{2}{*}{ Acetic acid } & 6 & $1 \cdot 17$ & $1 \cdot 01$ & 0.82 & 0.74 & \multirow{2}{*}{0.076} & $j^{* *}$ & NS \\
\hline & 22 & 1.07 & 0.95 & 0.76 & $0.73\}$ & & ** & NS \\
\hline \multirow[t]{2}{*}{ Propionic acid } & 6 & 0.032 & 0.027 & 0.058 & 0.044 & \multirow{2}{*}{0.0052} & j** & NS \\
\hline & 22 & 0.034 & 0.025 & 0.034 & $0.049\}$ & & $\{*$ & NS \\
\hline \multirow[t]{2}{*}{$n$-Butyric acid } & 6 & 0.019 & 0.021 & 0.021 & 0.020 & \multirow{2}{*}{0.0023} & fNS & NS \\
\hline & 22 & 0.022 & 0.021 & 0.015 & $0 \cdot 010$ & & $\{* *$ & NS \\
\hline \multirow[t]{2}{*}{ Isovaleric acid } & 6 & 0.029 & 0.041 & 0.041 & 0.045 & \multirow{2}{*}{0.0019} & f* & $* *$ \\
\hline & 22 & 0.044 & 0.047 & 0.032 & 0.035 & & $* * *$ & NS \\
\hline \multirow[t]{2}{*}{$n$-Valeric acid } & 6 & 0.022 & $0 \cdot 025$ & 0.017 & 0.018 & \multirow{2}{*}{0.0020} & $\int^{*}$ & NS \\
\hline & 22 & 0.022 & 0.021 & 0.018 & 0.012 & & $\{* *$ & NS \\
\hline \multirow[t]{2}{*}{ Glucose } & 6 & $3 \cdot 18$ & $3 \cdot 29$ & 4.08 & $3 \cdot 65$ & \multirow{2}{*}{0.169} & $\int^{* *}$ & NS \\
\hline & 22 & 3.42 & 3.62 & $4 \cdot 12$ & $4 \cdot 20$ & & $\{* *$ & NS \\
\hline \multirow{2}{*}{$\begin{array}{l}\text { Non-esterified fatty } \\
\text { acids }(\mu \mathrm{mol} / 1)\end{array}$} & 6 & 340 & 258 & 275 & $257)$ & \multirow{2}{*}{$21 \cdot 3$} & jNS & $*$ \\
\hline & 22 & 257 & 229 & 280 & $212\}$ & & INS & $*$ \\
\hline \multirow[t]{2}{*}{ 3-Hydroxybutyric acid } & 6 & $1.38 \S$ & 1.58 & 0.81 & 0.83 & \multirow{2}{*}{$0 \cdot 116$} & $\int^{* * *}$ & NS \\
\hline & 22 & $1 \cdot 36$ & $1 \cdot 32$ & $1 \cdot 19$ & $0.60\}$ & & (** & $*$ \\
\hline
\end{tabular}

NS, not significant.

$* P<0.05, * * P<0.01,{ }^{* * *} P<0.001$.

$\dagger$ Applicable to comparisons between treatment means at a given stage of lactation, based on the pooled variation between cows within treatments $(12 \mathrm{df})$ and the interaction between stage of lactation and cows within treatments (12 df).

\$ The only significant interactions $(P<0.05)$ were for propionic acid and 3-hydroxybutyric acid in mid-iactation.

$\S$ One large value omitted $(4 \cdot 34(\mathrm{mmol} / \mathrm{l}))$.

\section{DISCUSSION \\ Rumen fermentation}

More frequent feeding of the total diet greatly reduced the diurnal fluctuation in $\mathrm{pH}$ and the VFA concentration in the rumen in Expt 1. This effect is to be expected and is in agreement with similar work elsewhere (see Kaufmann \& Hagemeister, 1973). Minimum $\mathrm{pH}$ values tended to be higher with more frequent feeding, although with the low-roughage diets the difference was quite small, but the mean $\mathrm{pH}$ was lower with frequent feeding than with twice-daily feeding. The importance of this response in rumen $\mathrm{pH}$ for rumen metabolism is difficult to assess and depends on the relative importance of minimum $\mathrm{pH}$, mean $\mathrm{pH}$ or the length of time $\mathrm{pH}$ remains below a certain critical value. For instance cellulolysis is known to be sensitive to $\mathrm{pH}$, and a $\mathrm{pH}$ value of 6.0 is frequently suggested as the minimum below which cellulolysis may be severely inhibited. Although the lowest $\mathrm{pH}$ always occurred with twice-daily feeding, with frequent feeding $\mathrm{pH}$ remained at or below 6.0 all day for all the cows with the low-roughage diets and for two of the three cows with the normal diet, whereas with twice-daily feeding it was below 6.0 for only $2-6 \mathrm{~h}$ of the $12 \mathrm{~h}$ feeding cycle on the normal diet and $4 \cdot 5-8.5 \mathrm{~h}$ on the low-roughage diets. More frequent feeding increased organic matter digestibility in only one of the three experiments and fibre digestibility in only one of the two experiments in which it was measured (Sutton 
Table 7. Expt 3. Mean daily concentrations of various hormones in the plasma of cows at two stages of lactation (about 6 and 22 weeks of lactation) when they were given two diets each at two meal frequencies)

\begin{tabular}{|c|c|c|c|c|c|c|c|c|}
\hline \multirow{3}{*}{$\begin{array}{l}\text { Concentrates: hay... } \\
\text { No. of meals } / \mathrm{d} \ldots\end{array}$} & \multirow{3}{*}{$\begin{array}{c}\text { Stage } \\
\text { (weeks) }\end{array}$} & \multicolumn{2}{|c|}{$70: 30$} & \multicolumn{2}{|c|}{$90: 10$} & \multirow[b]{3}{*}{$\mathrm{SEM}^{\dagger}$} & & \\
\hline & & \multirow[t]{2}{*}{2} & \multirow[t]{2}{*}{6} & \multirow[t]{2}{*}{2} & \multirow[t]{2}{*}{6} & & \multicolumn{2}{|c|}{ Main effect $\$$} \\
\hline & & & & & & & Diet & Frequency \\
\hline \multirow[t]{2}{*}{ Prolactin (ng/ml) } & 6 & 5.4 & 3.8 & $4 \cdot 2$ & $5 \cdot 0\}$ & \multirow[b]{2}{*}{$1 \cdot 31$} & [NS & NS \\
\hline & 22 & $9 \cdot 5$ & 6.5 & $10 \cdot 8$ & $11.9\}$ & & $1 *$ & NS \\
\hline \multirow{2}{*}{$\begin{array}{l}\text { Growth hormone } \\
(\mathrm{ng} / \mathrm{ml})\end{array}$} & 6 & $6 \cdot 6$ & 6.0 & $5 \cdot 0$ & 4.9 & \multirow{2}{*}{$1 \cdot 20$} & NS & NS \\
\hline & 22 & $2 \cdot 2$ & $2 \cdot 4$ & 1.8 & $1 \cdot 2\}$ & & NS & NS \\
\hline \multirow{2}{*}{ Insulin $(\mu \mathrm{U} / \mathrm{ml})$} & 6 & $9 \cdot 6$ & 8.2 & 20.8 & $10.4\}$ & \multirow{2}{*}{$2 \cdot 82$} & j* & NS \\
\hline & 22 & $12 \cdot 2$ & 12.0 & 34.8 & $18.4\}$ & & $\{* * *$ & $*$ \\
\hline \multirow[t]{2}{*}{ Thyroxine $(\mathrm{ng} / \mathrm{ml})$} & 6 & $17 \cdot 2$ & $20 \cdot 8$ & $17 \cdot 6$ & $21.8\}$ & \multirow{2}{*}{2.79} & (NS & NS \\
\hline & 22 & 14.4 & 16.7 & $12 \cdot 9$ & $20.0\}$ & & l NS & NS \\
\hline \multirow{2}{*}{ Glucagon $(\mathrm{pg} / \mathrm{ml})$} & 6 & $27 \cdot 8$ & $25 \cdot 5$ & 36.2 & 28.71 & \multirow[b]{2}{*}{$10 \cdot 19$} & fNS & NS \\
\hline & 22 & 59.6 & 29.9 & 80.6 & $42.2\}$ & & $\left\{\begin{array}{l}\text { NS } \\
\text { nats }\end{array}\right.$ & $* *$ \\
\hline
\end{tabular}

NS, not significant.

* $P<0.05,{ }^{* *} P<0.01,{ }^{* * *} P<0.001$.

$\dagger$ Applicable to comparisons between treatment means at a given stage of lactation, based on the pooled variation between cows within treatments ( $12 \mathrm{df})$ and the interaction between stage of lactation and cows within treatments $(12 \mathrm{df})$.

$\ddagger$ The only significant interaction was for insulin in mid-lactation $(P<0.05)$.

et al. 1985), suggesting that the changes in $\mathrm{pH}$ brought about by increased feeding frequency had little net effect on digestive efficiency.

Rumen $\mathrm{pH}$ has also been shown to be closely related to other aspects of rumen fermentation, notably VFA proportions (see Sutton, 1976), but in this instance too the relative importance of mean or minimum $\mathrm{pH}$ values is unclear. In view of the considerable modifications to rumen $\mathrm{pH}$ that can be brought about by altering meal frequency and the influence of $\mathrm{pH}$ on rumen processes, it is clearly important to delineate these relations more accurately.

The effects of increasing meal frequency on rumen VFA proportions in these experiments were generally small and not significant, although there was a consistent trend for the proportion of acetic acid and the $(A+B) / P$ value to increase and the proportion of propionic acid to decrease. The changes in $n$-butyric acid were inconsistent. In the one experiment (Expt 1) in which each cow received both diets at both frequencies, the proportion of propionic fell in only one of the three cows in response to more frequent feeding of the low-roughage diet although it fell in all three cows when the normal diet was given more frequently.

Although the effects of feeding frequency on rumen VFA proportions in cattle have been reported in several studies, results have been inconsistent. The proportion of propionic acid has been reported to increase (Knox \& Ward, 1961), decrease (Kaufmann et al. 1975; Jensen \& Wolstrup, 1977) or remain unchanged (Bath \& Rook, 1963; Jorgensen et al. 1965) in response to more frequent feeding.

In addition to the small changes in the molar proportions of the major VFA in the present experiments, relatively large changes were found in the longer straight-chain VFA, particularly with the diets containing the higher proportions of concentrates. In these instances, the proportions of $n$-valeric acid and $n$-caproic acid tended to fall with more frequent feeding, but the reasons for this are far from clear. 


\section{Blood metabolites and hormones}

The very small and generally non-significant changes in concentrations of VFA in the peripheral blood due to altered meal frequency supported the conclusion that the products of rumen fermentation were also little affected by meal frequency. Indeed, the only blood metabolite whose concentration was clearly affected by more frequent feeding was NEFA, the concentration of which fell by about $17 \%$.

The responses in the concentration of blood metabolites to an increase in the proportion of concentrates in the diet broadly reflected the changes in rumen fermentation, namely a lower concentration of acetate and higher concentrations of propionate and glucose. The proportion of $n$-butyric acid in the rumen fell only slightly with the increase in the proportion of concentrates in the diet in Expt 3, and its concentration in the blood changed little, but the concentration of 3HBA in the blood fell by $40 \%$.

The changes in plasma hormone concentrations with stage of lactation have previously been noted and discussed by Hart et al. (1978). In the present experiment insulin concentration was lower with more frequent feeding at both stages of lactation, but the response was confined to animals receiving the diet containing $900 \mathrm{~g}$ concentrate $/ \mathrm{kg}$, no response being detected with animals given the lower-concentrate diet. Its concentration was also increased, at both stages of lactation, by a higher proportion of concentrates in the ration. This result has been reported by others (Walker \& Elliot, 1973; Evans et al. 1975) and may be related to the energy concentration of the ration and rate of VFA production in the rumen (Ostazewski \& Barej, 1979). Likewise the concentration of glucagon tended to be reduced by more frequent feeding and was higher with the higher-concentrate diet, but the responses were variable and only significant for feeding frequency in mid-lactation.

Several factors (neural, VFA, gastrointestinal hormones, amino acids) influence the post-prandial and energy-related changes in concentrations of circulating insulin and glucagon in ruminants, but the relative importance of these is poorly understood (Brockman, 1978). However, there is no doubt that changes in plasma VFA are an important component of the mechanisms controlling insulin and glucagon secretion in ruminants fed on high-concentrate diets and that propionate may play the predominant stimulatory role (de Jong, 1982; Bines \& Hart, 1984). This conclusion is supported by the fact that plasma concentrations of both propionate and insulin were significantly higher, at both stages of lactation, in the cows fed on the diet containing $900 \mathrm{~g}$ concentrates $/ \mathrm{kg}$. However, this argument cannot be applied to all situations. For instance, although more frequent feeding reduced the mean concentration of plasma insulin in mid-lactation in cows receiving $900 \mathrm{~g}$ concentrates $/ \mathrm{kg}$ this was accompanied by a small increase in plasma propionate concentration.

It has been suggested that isovaleric acid is considerably more potent than other rumen VFA in stimulating insulin secretion in sheep (Ambo et al. 1973), but the plasma concentrations of this metabolite tended to increase with increased feeding frequency and showed no obvious relation to insulin concentrations.

\section{Milk-fat concentration}

The principal production response to more frequent feeding in the present experiments was an increase in milk-fat concentration or, more precisely, a reduction in the milk-fat depression caused by giving low-roughage diets. In many experiments in which milk-fat concentration has been altered by varying forage:concentrates value, about two-thirds of the variation in milk-fat concentration can be related to changes in the molar proportions of VFA, whether these are expressed in terms of propionic acid (negative relation), acetate:propionate or $(\mathrm{A}+\mathrm{B}) / \mathrm{P}$ (positive relations). 
Table 8. Expts 3 and 4. Relation between milk fat concentration $(\mathrm{y}, \mathrm{g} / \mathrm{kg})$ and (acetic plus $\mathrm{n}$-butyric):propionic $((A+B) / P, \mathrm{x})$, for two meal frequencies

$$
\left(y=a+b x+c x^{2}\right)
$$

\begin{tabular}{|c|c|c|c|c|c|c|c|c|}
\hline \multirow{2}{*}{$\begin{array}{l}\text { No. of } \\
\text { meals } / \mathrm{d}\end{array}$} & \multicolumn{2}{|c|}{$a$} & \multicolumn{2}{|c|}{$b$} & \multicolumn{2}{|c|}{$c$} & \multirow[b]{2}{*}{$\mathrm{df}$} & \multirow[b]{2}{*}{$\% \mathrm{VAF}$} \\
\hline & Mean & $\mathbf{S E}$ & Mean & SE & Mean & $\mathrm{SE}$ & & \\
\hline \multicolumn{9}{|c|}{ Individual curves } \\
\hline 2 & $-13 \cdot 8$ & $10 \cdot 88$ & $19 \cdot 7^{*}$ & 6.64 & $-2 \cdot 0$ & 0.92 & 13 & 82 \\
\hline 6 & 5.9 & $6 \cdot 46$ & $12 \cdot 7^{* *}$ & 3.52 & $-1 \cdot 3^{*}$ & 0.45 & 13 & 67 \\
\hline \multicolumn{9}{|c|}{ Parallel curves $\dagger$} \\
\hline $\begin{array}{l}2 \\
6\end{array}$ & $\begin{array}{l}-6 \cdot 5 \\
-2 \cdot 3\end{array}$ & $\left.\begin{array}{l}5 \cdot 61 \\
5.53\end{array}\right\}$ & $16 \cdot 3^{* * *}$ & $3 \cdot 18$ & $-1 \cdot 6^{* * *}$ & 0.42 & 28 & 76 \\
\hline
\end{tabular}

VAF, variation accounted for by the relation.

${ }^{*} P<0.05,{ }^{* *} P<0.01,{ }^{* * *} P<0.001$.

$\dagger$ Relations were parallel but not coincident.

Kaufmann et al. (1975) reported similar production responses to those in the present experiments and concluded that it was the increased acetate:propionate in the rumen with more frequent feeding that accounted for the higher milk-fat concentration. However, the changes in rumen VFA in the present studies were very small and, in the case of cow $B$ in Expt 1, $(\mathrm{A}+\mathrm{B}) / \mathrm{P}$ actually fell with more frequent feeding of the low-roughage diet yet milk-fat concentration increased markedly $(22.2 v .37 \cdot 6 \mathrm{~g} / \mathrm{kg})$.

To examine the relations between milk-fat concentration and $(\mathrm{A}+\mathrm{B}) / \mathrm{P}$, the results of Expts 3 and 4 were combined, as the designs of the experiments were very similar and the data overlapped. Curvilinear regressions were established for the two meal frequencies (Table 8). The shapes of the curves could not be distinguished statistically so parallel curves were calculated.

These calculations confirm the close relation between milk-fat concentration and rumen VFA proportions, about $76 \%$ of the variation in milk-fat concentration being related to $(\mathrm{A}+\mathrm{B}) / \mathrm{P}$. However, the important point in the context of the present paper is that the intercepts of the curves were significantly different for the two frequencies. The fact that, for any given $(A+B) / P$ value, milk-fat concentration was higher with more frequent feeding implies that an additional factor must be sought to explain the difference in milk-fat concentration brought about by changing meal frequency. In coming to this conclusion it must of course be recognized that the method of obtaining rumen samples in these experiments prevented the frequent sampling desirable to obtain an accurate measure of the rumen molar proportions of VFA with twice-daily feeding. Furthermore, the relation between the molar proportions of VFA found in the rumen and the molar proportions produced is poorly defined (Sutton, 1985).

Although there is general agreement that the milk-fat depression with low-roughage diets is usually associated with high proportions of propionic acid in the rumen VFA, there is no such unanimity about the direct metabolic causes of this change in milk-fat production, and various theories have been proposed. The results of the present experiment strongly support the theory, first propounded by McClymont \& Vallance (1962), that elevated plasma insulin is a key factor causing low milk-fat concentrations. Thus the severe milk-fat depression with twice-daily feeding of the diet containing $900 \mathrm{~g}$ concentrates $/ \mathrm{kg}$ in Expt 3 can be interpreted in terms of an increase in the proportion of propionic acid in the rumen causing the concentration of propionic acid or glucose to increase in the plasma, and this in turn stimulating insulin release. One effect of high plasma insulin is to inhibit lipolysis 
and increase lipogenesis in adipose tissue which, by reducing precursor supplies to the udder, reduces milk-fat synthesis (Hart, 1983). The fact that plasma NEFA concentrations were only reduced by the low-roughage diet in early lactation is not evidence against this theory, as there is little relation between turnover rates and concentrations.

If this is accepted as a reasonable hypothesis to explain the milk-fat depression, then it is logical to seek the cause of the reduction in milk-fat depression brought about by more frequent feeding in a reversal of these trends. In fact the changes in rumen propionate and the mean concentrations of plasma propionate and glucose in response to more frequent feeding were small, and NEFA concentrations actually fell. There was a significant fall in the mean concentration of plasma insulin for the diet containing $900 \mathrm{~g}$ concentrates $/ \mathrm{kg}$, and this offers an explanation for the higher milk-fat concentration with that diet. However, with the lower-concentrate diet, although more frequent feeding markedly increased the yield and concentration of milk fat, it had no effect on the mean concentration of plasma insulin, and additional control mechanisms must therefore be sought to explain this production response.

The authors are grateful to Messrs D. J. Hathorn, A. D. Simmonds and R. A. D. Hora for skilled technical assistance.

\section{REFERENCES}

Alford, F. P., Bloom, S. R. \& Nabarro, D. N. (1977). Diabetologia 13, 1-6.

Ambo, K., Takahashi, H. \& Tsuda, T. (1973). Tohuku Journal of Agricultural Research 24, 54-62.

Bath, I. H. \& Rook, J. A. F. (1963). Journal of Agricultural Science, Cambridge 61, 341-348.

Bines, J. A. \& Hart, I. C. (1984). Canadian Journal of Animal Science 64 Suppl., 304-305.

Brockman, R. P. (1978). Canadian Veterinary Journal 19, 55-62.

de Jong, A. (1982). Journal of Endocrinology 92, 357-370.

Evans, E., Buchanan-Smith, J. G. \& MacLeod, G. K. (1975). Journal of Animal Science 41, 1474-1479.

Hart, I. C. (1983). Proceedings of the Nutrition Society 42, 181-194.

Hart, I. C., Bines, J. A., Morant, S. V. \& Ridley, J. L. (1978). Journal of Endocrinology 77, 333-345.

Jensen, K. \& Wolstrup, J. (1977). Acta Veterinaria Scandinavica 18, 108-121.

Jorgensen, N. A., Schultz, L. H. \& Barr, G. R. (1965). Journal of Dairy Science 48, 1031-1039.

Kaufmann, W. \& Hagemeister, H. (1973). Übersicht der Tierernährung 1, 193-221.

Kaufmann, W., Rohr, K., Daenicke, R. \& Hagemeister, H. (1975). Sonderheft der Berichte über Landwirtschaft 191, 269-295.

Knox, K. L. \& Ward, G. M. (1961). Journal of Dairy Science 44, 1550-1553.

McClymont, G. L. \& Vallance, S. (1962). Proceedings of the Nutrition Society 21, xli.

Ostazewski, P. \& Barej, W. (1979). Annales de Recherches Vétérinaires 10, 385-387.

Sutton, J. D. (1976). In Principles of Cattle Production, pp. 121-143 [H. Swan and W. H. Broster, editors]. London: Butterworths.

Sutton, J. D. (1985). Journal of Dairy Science 68, 3376-3393.

Sutton, J. D., Broster, W. H., Napper, D. J. \& Siviter, J. W. (1985). British Journal of Nutrition 53, 117-130.

Sutton, J. D. \& Johnson, V. W. (1969). Journal of Agricultural Science, Cambridge 73, 459-468.

Walker, C. K. \& Elliot, J. M. (1973). Journal of Dairy Science 56, 375-377. 